\title{
RESPONS PERTUMBUHAN DAN HASIL TIGA VARIETAS SORGUM (Sorghum bicolor (L.) Moench) RATOON I TERHADAP APLIKASI BAHAN ORGANIK TANAMAN SORGUM PERTAMA
}

\author{
Novri, Muhammad Kamal, Sunyoto \& Kuswanta Futas Hidayat \\ Jurusan Agroteknologi, Fakultas Pertanian Universitas Lampung \\ Jl. Prof. Soemantri Brodjonegoro, No. 1 Bandar Lampung 35145 \\ Email: novry.sultan@yahoo.com
}

\begin{abstract}
ABSTRAK
Penelitian ini bertujuan untuk mengetahui pengaruh dosis bahan organik yang diaplikasikan pada tanaman sorgum pertama terhadap pertumbuhan dan hasil tanaman sorgum ratoon I, pertumbuhan dan hasil tanaman sorgum ratoon I yang terbaik pada tiga varietas yang dicoba, dan mengetahui pengaruh interaksi antara dosis bahan organik yang diaplikasikan pada tanaman sorgum pertama dengan tiga varietas yang dicoba terhadap pertumbuhan dan hasil tanaman sorgum ratoon I. Penelitian ini dilaksanakan di Balai Pengkajian Teknologi Pertanian (BPTP) Kebun Percobaan Natar, Desa Negara Ratu, Kecamatan Natar, Kabupaten Lampung Selatan dan Laboratorium Ilmu Tanaman, Fakultas Pertanian, Universitas Lampung yang dilaksanakan pada bulan September sampai dengan Desember 2013. Perlakuan disusun secara faktorial dengan Rancangan Petak Terbagi (Split Plot Design) dalam Rancangan Kelompok Teracak Sempurna (RKTS) dengan tiga ulangan. Petak percobaan yang digunakan pada penelitian ini berukuran $4 \mathrm{~m} \times 4 \mathrm{~m}$. Tiap satu satuan percobaan seluas $16 \mathrm{~m}^{2}$ dengan jarak tanam $80 \times 20 \mathrm{~cm}$. Hasil penelitian menunjukkan bahwa ; Perlakuan dosis bahan organik 15 ton/ha menghasilkan bobot biji/malai sorgum ratoon I tertinggi yaitu 45,64 g/tanaman atau setara $285,25 \mathrm{~g} / \mathrm{m}^{2}$; Varietas Numbu menunjukkan hasil bobot biji/ malai sorgum ratoon I tertinggi yaitu $55,37 \mathrm{~g} / \operatorname{tanaman}$ atau setara $346,06 \mathrm{~g} / \mathrm{m}^{2}$ sedangkan, varietas Wray menghasilkan bobot brangkasan basah tertinggi, yaitu $0,54 \mathrm{~kg} /$ tanaman atau setara $3,37 \mathrm{~kg} / \mathrm{m}^{2} ;$ dan Kombinasi antara dosis bahan organik dan varietas sorgum yang tepat untuk menghasilkan bobot brangkasan basah tertinggi adalah dosis bahan organik 5 ton/ha dengan varietas Wray yaitu $0,54 \mathrm{~kg} / \operatorname{tanaman}$ atau setara $3,37 \mathrm{~g} / \mathrm{m}^{2}$.
\end{abstract}

Kata kunci: bahan organik, hasil, pertumbuhan, varietas, ratoon I, sorgum

\section{PENDAHULUAN}

Ketahanan pangan dan krisis energi sampai saat ini masih menjadi salah satu perhatian utama dalam pembangunan nasional. Usaha peningkatan produksi bahan pangan terus dilakukan untuk memenuhi kebutuhan pangan terutama makanan pokok sejalan dengan laju pertambahan penduduk. Usaha ini tidak terbatas pada tanaman utama (padi) melainkan penganekaragaman (diversifikasi) dengan mengembangkan tanaman pangan alternatif sumber bahan pangan. Sorgum merupakan komoditas pangan alternatif yang memiliki potensi cukup besar untuk dikembangkan di Indonesia. Biji sorgum dapat digunakan sebagai bahan pangan yang banyak mengandung karbohidrat sebagai bahan dasar pembuatan minuman dan pakan ternak (Mudjisihono dan Damardjati, 1987).

Upaya yang dapat dilakukan untuk meningkatkan pertumbuhan dan perkembangan serta kualitas hasil tanaman sorgum adalah dengan memberikan suplai hara yang cukup dan seimbang melalui pemupukan yang dapat memperbaiki kondisi tanah dengan cara penambahan pupuk organik dalam tanah. Menurut penelitian Sucipto (2011), tentang efektivitas cara pemupukan terhadap pertumbuhan dan hasil beberapa varietas sorgum manis menunjukkan bahwa pemberian pupuk akan memberikan hasil terbaik terhadap pertumbuhan seperti tinggi tanaman, diameter batang, jumlah daun serta berat biji kering.

Perbedaan varietas sorgum akan mengacu pada faktor genetik pada masing-masing varietas sorgum. Faktor genetik merupakan salah satu penentu pada pertumbuhan dan hasil pada tanaman sorgum. Menurut Tarigan dkk. (2013), bahwa varietas Numbu mampu memberikan hasil tertinggi pada pengamatan produksi per tanaman, produksi per plot, produksi per ha, bobot basah tajuk, dan bobot 1000 biji dibandingkan dengan varietas lainnya. Setiap genotipe yang berbeda akan memiliki keunggulan yang berbeda-beda pula, dalam memanfaatkan faktor lingkungan seperti air, cahaya, dan unsur hara sehingga dapat mempengaruhi pertumbuhan dan perkembangan tanaman (Septiani, 2009).

Untuk itu dilakukan penelitian ini dengan tujuan; mengetahui pengaruh dosis bahan organik yang diaplikasikan pada tanaman sorgum pertama terhadap 
pertumbuhan dan hasil tanaman sorgum ratoon I; mengetahui pertumbuhan dan hasil tanaman sorgum ratoon I yang terbaik pada tiga varietas yang dicoba; dan mengetahui pengaruh interaksi antara dosis bahan organik yang diaplikasikan pada tanaman sorgum pertama dengan tiga varietas yang dicoba terhadap pertumbuhan dan hasil tanaman sorgum ratoon I.

\section{BAHAN DAN METODE}

Penelitian ini dilaksanakan di Kebun Percobaan Balai Pengkajian Teknologi Pertanian (BPTP) Natar, Desa Negara Ratu, Kecamatan Natar, Kabupaten Lampung Selatan dan Laboratorium Ilmu Tanaman, Fakultas Pertanian, Universitas Lampung yang dilaksanakan pada bulan September sampai dengan Desember 2013. Perlakuan disusun secara faktorial dengan Rancangan Petak Terbagi (Split Plot Design) dalam Rancangan Kelompok Teracak Sempurna (RKTS) dengan tiga ulangan. Petak utama adalah dosis bahan organik dari pupuk kandang sapi (B), yaitu 0 (b0), 5 (b1), 10 (b2), dan 15 (b3) ton ha ${ }^{-1}$ sedangkan anak petak adalah varietas sorgum $(\mathrm{G})$, yang terdiri dari varietas Numbu (g1), Keller (g2), dan Wray (g3). Petak percobaan yang digunakan pada penelitian ini berukuran $4 \mathrm{~m} \times 4 \mathrm{~m}$. Tiap satu satuan percobaan seluas $16 \mathrm{~m}^{2}$ dengan jarak tanam $80 \times 20 \mathrm{~cm}$. Susunan perlakuan dapat dilihat pada Tabel 1 .

Setelah memasuki umur panen pada musim pertama segera dilakukan pemotongan batang tua $( \pm$ $10-15 \mathrm{~cm}$ ) di atas permukaan tanah atau $5 \mathrm{~cm}$ di atas akar adventif. Perbaikan petakan setelah pemotongan tanaman pertama meliputi pembumbunan antara tanaman sorgum dan pembuatan paritan-paritan disekeliling petakan. Penjarangan dilakukan dengan cara membuang sebagian tunas-tunas baru yang telah muncul di permukaan tanah. Penjarangan dilakukan \pm 2 minggu setelah tanaman sorgum ratoon I muncul dari permukaan tanah. Pemberian bahan organik yaitu pupuk kandang sapi diberikan pada saat awal pertanaman sorgum pertama dengan dosis $0,5,10$, dan 10 ton ha ${ }^{-1}$. Pemupukan menggunakan pupuk kimia Urea, SP36, dan $\mathrm{KCl}$ dengan dosis masing-masing 100,100, dan $150 \mathrm{~kg}$ $\mathrm{ha}^{-1}$, atau dosis pupuk per petaknya yaitu Urea $160 \mathrm{~g}$, SP36 160 g, dan $\mathrm{KCl} 240$ g. Selain itu dilakukan pemeliharaan meliputi penyiraman, pembumbunan, dan pengendalian hama serta penyakit termasuk pengendalian gulma.

Jumlah tanaman yang diamati adalah 5 tanaman setiap petak yang dipilih secara acak. Variabel yang diamati pada komponen pertumbuhan meliputi : (1) tinggi tanaman, (2) jumlah daun, (3) diameter batang, (4) tingkat kehijauan daun ketiga, variabel ini diamati sejak tanaman berumur 4 sampai 9 mst, sedangkan pada komponen hasil meliputi : (1) bobot brangkasan basah, (2) bobot brangkasan kering, (3) panjang malai, (4) jumlah biji/ malai, (5) bobot biji/ malai, dan (6) bobot 100 butir biji yang diamati setelah tanaman dipanen pada umur 14 mst.

\section{HASIL DAN PEMBAHASAN}

Berdasarkan hasil penelitian respons pertumbuhan dan hasil beberapa varietas tanaman sorgum (Sorghum bicolor (L.) Moench) ratoon I terhadap aplikasi bahan organik tanaman sorgum pertama menunjukkan bahwa pertumbuhan dan hasil tanaman sorgum ratoon $\mathrm{I}$ dipengaruhi oleh bahan organik dan varietas sorgum.

Tinggi tanaman pada umur 4, 5, dan 6 mst dosis bahan organik 15 ton/ha menunjukkan hasil yang lebih tinggi daripada dosis bahan organik 5 dan 0 ton hanamun tidak berbeda nyata dengan dosis 10 ton/ha;

Tabel 1. Kombinasi perlakuan dalam peneltian

\begin{tabular}{ccc}
\hline Kombinasi Perlakuan & Bahan Organik $\left(\right.$ ton ha $\left.^{-1}\right)$ & Varietas \\
\hline b0g1 & 0 & Numbu \\
b0g2 & 0 & Keller \\
b0g3 & 0 & Wray \\
b1g1 & 5 & Numbu \\
b1g2 & 5 & Keller \\
b1g3 & 5 & Wray \\
b2g1 & 10 & Numbu \\
b2g2 & 10 & Keller \\
b2g3 & 10 & Wray \\
b3g1 & 15 & Numbu \\
b3g2 & 15 & Keller \\
b3g3 & 15 & Wray \\
\hline
\end{tabular}


sedangkan pada umur 7 dan 8 mst tidak berbeda nyata dengan dosis bahan organik 10 dan 5 ton ha-1 (Tabel 2). Hal tersebut diduga karena adanya perbedaan pengaplikasian dosis bahan organik yang berbeda, semakin tinggi dosis bahan organik yang diaplikasikan maka semakin tinggi suplai unsur hara di dalam tanah. Menurut Yasin yang dikutip oleh Sucipto (2010), bahwa keseimbangan unsur hara akan meningkatkan pertumbuhan tanaman. Tanaman sorgum yang diberi pupuk dengan dosis yang berbeda-beda akan mengalami respon yang berbeda pula, dan sangat mungkin setiap genotipe berbeda pula dalam tanggapannya yang dimunculkan dalam fenotipe tanaman (Hamim dan Sunyoto, 2011).

Pada jumlah daun umur $6 \mathrm{mst}$ dosis bahan organik 15 ton ha $^{-1}$ menunjukkan hasil yang lebih tinggi daripada dosis 0 ton $\mathrm{ha}^{-1}$, namun tidak berbeda nyata dengan dosis bahan organik 10 dan 5 ton ha ${ }^{-1}$ (Tabel 3). Pada tingkat

Tabel 2. Pengaruh bahan organik dan varietas sorgum terhadap tinggi tanaman sorgum ratoon 1 pada umur 4 , $5,6,7,8$ dan 9 mst

\begin{tabular}{lcccccc}
\hline \multirow{2}{*}{ Perlakuan } & \multicolumn{5}{c}{ Umur Tanaman (MST) } \\
\cline { 2 - 7 } & 4 & 5 & 6 & 7 & 8 & 9 \\
\hline Bahan Organik & & & & & \\
b0 $\left(0\right.$ to ha $\left.^{-1}\right)$ & $76,10 \mathrm{c}$ & $91,71 \mathrm{c}$ & $124,22 \mathrm{c}$ & $161,10 \mathrm{~b}$ & $196,53 \mathrm{~b}$ & $219,29 \mathrm{a}$ \\
b1 $\left(5\right.$ ton ha $\left.^{-1}\right)$ & $88,81 \mathrm{~b}$ & $107,09 \mathrm{~b}$ & $148,22 \mathrm{~b}$ & $190,76 \mathrm{a}$ & $212,80 \mathrm{a}$ & $216,56 \mathrm{a}$ \\
b2 $\left(10\right.$ ton $\left.\mathrm{ha}^{-1}\right)$ & $96,02 \mathrm{ab}$ & $119,76 \mathrm{a}$ & $161,51 \mathrm{ab}$ & $200,44 \mathrm{a}$ & $215,29 \mathrm{a}$ & $215,29 \mathrm{a}$ \\
b3 $\left(15\right.$ ton ha $\left.\mathrm{h}^{-1}\right)$ & $102,23 \mathrm{a}$ & $127,06 \mathrm{a}$ & $168,49 \mathrm{a}$ & $203,49 \mathrm{a}$ & $214,78 \mathrm{a}$ & $212,78 \mathrm{a}$ \\
\hline Nilai BNJ 0,05 & 7,89 & 11,79 & 13,93 & 13,62 & 7,82 & 11,90 \\
\hline Varietas & $92,54 \mathrm{a}$ & $107,98 \mathrm{a}$ & $147,42 \mathrm{a}$ & $188,20 \mathrm{a}$ & $207,92 \mathrm{a}$ & $217,98 \mathrm{a}$ \\
Numbu & $90,56 \mathrm{a}$ & $111,18 \mathrm{a}$ & $153,30 \mathrm{a}$ & $194,22 \mathrm{a}$ & $210,55 \mathrm{a}$ & $216,53 \mathrm{a}$ \\
Keller & $89,28 \mathrm{a}$ & $115,05 \mathrm{a}$ & $151,12 \mathrm{a}$ & $184,43 \mathrm{a}$ & $211,08 \mathrm{a}$ & $213,42 \mathrm{a}$ \\
Wray & 6,16 & 9,21 & 10,88 & 10,64 & 6,11 & 9,30 \\
\hline Nilai BNJ 0,05 &
\end{tabular}

Keterangan: Angka yang diikuti huruf yang sama pada umur yang sama dalam setiap kolom tidak berbeda nyata berdasarkan uji BNJ $5 \%$.

Tabel 3. Pengaruh bahan organik dan varietas sorgum terhadap jumlah daun tanaman sorgum ratoon 1 pada umur 5, 6, 7, 8, dan 9 mst

\begin{tabular}{lccccc}
\hline \multirow{2}{*}{ Perlakuan } & \multicolumn{5}{c}{ Umur Tanaman (MST) } \\
\cline { 2 - 5 } & 5 & 6 & 7 & 8 & 9 \\
\hline Bahan Organik & & & & \\
b0 (0 ton/ha) & $7,58 \mathrm{a}$ & $8,18 \mathrm{~b}$ & $9,36 \mathrm{a}$ & $10,56 \mathrm{a}$ & $10,78 \mathrm{a}$ \\
b1 (5 ton/ha) & $8,22 \mathrm{a}$ & $8,64 \mathrm{ab}$ & $9,49 \mathrm{a}$ & $10,38 \mathrm{a}$ & $10,56 \mathrm{a}$ \\
b2 (10 ton/ha) & $8,24 \mathrm{a}$ & $8,80 \mathrm{ab}$ & $9,60 \mathrm{a}$ & $10,29 \mathrm{a}$ & $10,40 \mathrm{a}$ \\
b3 (15 ton/ha) & $8,27 \mathrm{a}$ & $9,33 \mathrm{a}$ & $9,89 \mathrm{a}$ & $10,13 \mathrm{a}$ & $10,13 \mathrm{a}$ \\
\hline Nilai BNJ 0,05 & 0,69 & 0,79 & 0,63 & 0,59 & 0,84 \\
\hline Varietas & & & & $10,13 \mathrm{a}$ & $10,23 \mathrm{a}$ \\
Numbu & $7,73 \mathrm{~b}$ & $8,37 \mathrm{~b}$ & $9,47 \mathrm{a}$ & $10,32 \mathrm{a}$ & $10,43 \mathrm{a}$ \\
Keller & $8,00 \mathrm{ab}$ & $8,85 \mathrm{ab}$ & $9,57 \mathrm{a}$ & $10,57 \mathrm{a}$ & $10,73 \mathrm{a}$ \\
Wray & $8,50 \mathrm{a}$ & $9,00 \mathrm{a}$ & $9,72 \mathrm{a}$ & 0,46 & 0,66 \\
\hline Nilai BNJ 0,05 & 0,54 & 0,62 & 0,49 & & \\
\hline
\end{tabular}

Keterangan: Angka yang diikuti huruf yang sama pada umur yang sama dalam setiap kolom tidak berbeda nyata berdasarkan uji BNJ $5 \%$. 
kehijauan daun ketiga umur 6, 7, dan 8 (Tabel 4) dosis bahan organik 15 ton ha ${ }^{-1}$ memiliki tingkat kehijauan daun lebih tinggi daripada dosis bahan organik 5 dan 0 ton ha ${ }^{-}$ ${ }^{1}$, namun tidak berbeda nyata dengan dosis bahan organik 10 ton ha ${ }^{-1}$. Pada komponen hasil bobot biji/malai serta bobot 100 butir biji (Tabel 5) dosis bahan organik 15 ton ha $^{-1}$ menunjukkan hasil yang lebih tinggi, namun tidak berbeda nyata dengan 10 dan 5 ton ha ${ }^{-1}$. Hal ini menunjukkan bahwa pemberian pupuk kandang dengan jumlah yang banyak dapat mendukung ketersediaan unsur hara di dalam tanah. Selain itu, pemberian pupuk kandang ini juga dapat memelihara kesuburan tanah

Tabel 4. Pengaruh bahan organik dan varietas sorgum terhadap tingkat kehijauan daun ketiga tanaman sorgum ratoon 1 pada umur $6,7,8$, dan 9 mst

\begin{tabular}{lcccc}
\hline & \multicolumn{4}{c}{ Umur Tanaman (MST) } \\
\cline { 2 - 4 } Perlakuan & 6 & 7 & 8 & 9 \\
\hline Bahan Organik & $39,44 \mathrm{c}$ & $45,08 \mathrm{c}$ & $45,76 \mathrm{c}$ & $40,84 \mathrm{a}$ \\
b0 $\left(0\right.$ ton $\left.\mathrm{ha}^{-1}\right)$ & $41,07 \mathrm{bc}$ & $47,53 \mathrm{bc}$ & $48,87 \mathrm{bc}$ & $44,92 \mathrm{a}$ \\
b1 $\left(5\right.$ ton $\left.\mathrm{ha}^{-1}\right)$ & $43,10 \mathrm{ab}$ & $49,70 \mathrm{ab}$ & $50,15 \mathrm{ab}$ & $36,98 \mathrm{a}$ \\
b2 $\left(10{\left.\text { ton } \mathrm{ha}^{-1}\right)}^{-1}\right.$ & $45,39 \mathrm{a}$ & $52,80 \mathrm{a}$ & $53,19 \mathrm{a}$ & $41,37 \mathrm{a}$ \\
\hline b3 $\left(15\right.$ ton $\left.\mathrm{ha}^{-1}\right)$ & 2,84 & 3,97 & 3,58 & 8,09 \\
\hline Nilai BNJ 0,05 & & & & $32,39 \mathrm{a}$ \\
\hline Varietas & $40,83 \mathrm{~b}$ & $48,28 \mathrm{a}$ & $49,35 \mathrm{a}$ & $46,79 \mathrm{a}$ \\
Numbu & $42,66 \mathrm{ab}$ & $49,24 \mathrm{a}$ & $49,81 \mathrm{a}$ & $43,90 \mathrm{a}$ \\
Keller & $43,27 \mathrm{a}$ & $48,82 \mathrm{a}$ & $49,33 \mathrm{a}$ & 6,32 \\
Wray & 2,22 & 3,10 & 2,80 & \\
\hline Nilai BNJ 0,05 & & & \\
\hline
\end{tabular}

Keterangan: Angka yang diikuti huruf yang sama pada umur yang sama dalam setiap kolom tidak berbeda nyata berdasarkan uji BNJ $5 \%$.

Tabel 5. Pengaruh bahan organik dan varietas sorgum terhadap bobot brangkasan kering, panjang malai, jumlah biji/ malai, bobot biji/malai dan bobot 100 butir biji tanaman sorgum ratoon 1

\begin{tabular}{lccccc}
\hline \multicolumn{1}{c}{ Perlakuan } & $\begin{array}{c}\text { Bobot } \\
\text { brangkasan } \\
\text { kering } \\
(\text { kg/tanaman })\end{array}$ & $\begin{array}{c}\text { Panjang } \\
\text { malai } \\
(\mathrm{cm})\end{array}$ & $\begin{array}{c}\text { Jumlah biji// } \\
\text { malai } \\
(\text { butir })\end{array}$ & $\begin{array}{c}\text { Bobot biji/ } \\
\text { malai } \\
(\mathrm{g})\end{array}$ & $\begin{array}{c}\text { Bobot 100 butir } \\
\text { biji } \\
(\mathrm{g})\end{array}$ \\
\hline $\begin{array}{l}\text { Bahan Organik } \\
\left(\text { ton ha }{ }^{-1}\right)\end{array}$ & & & & \\
0 & $0,08 \mathrm{a}$ & $22,72 \mathrm{a}$ & $1.329,80 \mathrm{a}$ & $28,04 \mathrm{~b}$ & $2,07 \mathrm{~b}$ \\
5 & $0,08 \mathrm{a}$ & $22,62 \mathrm{a}$ & $1.259,30 \mathrm{a}$ & $31,29 \mathrm{ab}$ & $2,42 \mathrm{ab}$ \\
10 & $0,09 \mathrm{a}$ & $23,99 \mathrm{a}$ & $1.500,50 \mathrm{a}$ & $39,40 \mathrm{ab}$ & $2,50 \mathrm{a}$ \\
15 & $0,08 \mathrm{a}$ & $23,96 \mathrm{a}$ & $1.478,70 \mathrm{a}$ & $45,64 \mathrm{a}$ & $2,67 \mathrm{a}$ \\
\hline Nilai BNJ 0,05 & 0,02 & 2,45 & 486,33 & 15,57 & 0,38 \\
\hline Varietas Sorgum & $0,07 \mathrm{~b}$ & $21,14 \mathrm{c}$ & $1.922,70 \mathrm{a}$ & $55,37 \mathrm{a}$ & $2,82 \mathrm{a}$ \\
Numbu & $0,09 \mathrm{a}$ & $25,42 \mathrm{a}$ & $1.327,60 \mathrm{~b}$ & $29,61 \mathrm{~b}$ & $2,02 \mathrm{c}$ \\
Keller & $0,08 \mathrm{ab}$ & $23,41 \mathrm{~b}$ & $925,90 \mathrm{c}$ & $23,30 \mathrm{~b}$ & $2,41 \mathrm{~b}$ \\
Wray & 0,01 & 1,92 & 379,85 & 12,16 & 0,30 \\
\hline Nilai BNJ 0,05 & & & & \\
\hline
\end{tabular}

Keterangan: Angka yang diikuti huruf yang sama pada umur yang sama dalam setiap kolom tidak berbeda nyata berdasarkan uji BNJ $5 \%$. 
sehingga tanaman dapat tumbuh dan memberikan hasil yang baik. Menurut Sitompul dan Guritno (1995), Tanaman akan memberikan reaksi atau tanggapan terhadap perubahan lingkungan dengan tingkat tanggapan yang tergantung pada jenis tanaman dan tingkat perubahan lingkungan tersebut.

Perlakuan varietas sorgum yang menunjukkan hasil lebih tinggi terhadap jumlah daun pada umur 5 dan 6 mst terdapat pada varietas Wray, namun tidak berbeda nyata dengan varietas Keller (Tabel 3). Pada diameter batang umur 4 dan 5 mst varietas Wray menunjukkan hasil yang lebih tinggi daripada varietas Numbu, namun tidak berbeda nyata dengan varietas Keller. Akan tetapi, pada umur 7 mst varietas Keller menunjukkan hasil yang lebih tinggi daripada varietas Keller, namun tidak berbeda nyata dengan varietas Wray (Tabel 6). Hal tersebut diduga karena setiap varietas yang berbeda mempunyai kemampuan genetik yang berbeda, masing-masing varietas sorgum memberikan respon pertumbuhan yang berbeda pula terhadap lingkungan tumbuhnya. Hal ini selaras dengan pernyataan Subeni dalam Sucipto (2010), bahwa potensi tumbuh tanaman sorgum dipengaruhi oleh sifat genetis varietas, kondisi atau iklim dan lingkungan tempat tumbuh serta perlakuan budidayanya.

Laju fotosintesis daun dipangaruhi oleh faktor internal di dalam daun yaitu kandungan klorofil daun dalam memproduksi klorofil daun. Daun yang memiliki kandungan klorofil tinggi diharapkan lebih efisien dalam menangkap energi cahaya matahari untuk fotosintesis (Gardner et al., 1991). Pada tingkat kehijauan daun ketiga (Tabel 4) pada umur 6 mst varietas Wray menunjukkan hasil yang lebih tinggi daripada varietas Numbu, namun tidak berbeda nyata dengan varietas Keller. Menurut Septiani (2009), setiap genotipe yang berbeda akan memiliki keunggulan yang berbeda-beda pula, dalam memanfaatkan faktor lingkungan seperti air, cahaya, dan unsur hara sehingga dapat mempengaruhi pertumbuhan dan perkembangan tanaman.

Pada komponen hasil (Tabel 5) bobot brangkasan kering varietas Keller menunjukkan hasil yang lebih tinggi daripada varietas Numbu, namun tidak berbeda nyata dengan varietas Wray; sedangkan pada panjang malai varietas Keller menunjukkan hasil tertinggi dibandingkan varietas Wray dan Numbu. Pada jumlah biji/malai, bobot biji/ malai, dan bobot 100 butir bji varietas Numbu menunjukkan hasil tertinggi dibandingkan varietas Wray dan Keller. Hal ini sesuai dengan penelitian Wahida dkk. (2003), bahwa varietas Numbu memiliki bobot 1000 biji, bobot biji per malai, dan bobot biji kering per petak yang lebih tinggi karena varietas Numbu lebih respon terhadap pemberian pupuk.

Pada jumlah daun 4 mst, dan bobot brangkasan basah (Tabel 7 dan Tabel 8) terjadi pengaruh interaksi antara bahan organik dengan varietas sorgum. Adanya ketergantungan bahan organik dengan varietas sorgum menunjukkan bahwa dengan genetik tanaman yang berbeda maka respon terhadap lingkungan yang berbeda akan berbeda pula.

Dari hasil penelitian, tanaman sorgum ratoon I yang memiliki bobot brangkasan kering tertinggi belum

Tabel 6. Pengaruh bahan organik dan varietas sorgum terhadap diameter batang tanaman sorgum ratoon 1 pada umur 4, 5, 6, 7, 8, dan 9 mst

\begin{tabular}{|c|c|c|c|c|c|c|}
\hline \multirow{2}{*}{ Perlakuan } & \multicolumn{6}{|c|}{ Umur Tanaman (MST) } \\
\hline & 4 & 5 & 6 & 7 & 8 & 9 \\
\hline Bahan Organik & & & & & & \\
\hline b0 $\left(\right.$ ton $\left.\mathrm{ha}^{-1}\right)$ & $12,82 \mathrm{a}$ & $13,77 \mathrm{a}$ & $15,66 \mathrm{a}$ & $17,07 \mathrm{a}$ & $17,42 \mathrm{a}$ & $17,77 \mathrm{a}$ \\
\hline b1 $\left(5\right.$ ton $\left.\mathrm{ha}^{-1}\right)$ & $13,29 \mathrm{a}$ & $15,35 \mathrm{a}$ & $16,73 a$ & $17,29 a$ & $18,30 \mathrm{a}$ & $18,40 \mathrm{a}$ \\
\hline b2 (10 ton ha $\left.{ }^{-1}\right)$ & $13,86 \mathrm{a}$ & $15,08 \mathrm{a}$ & $17,56 \mathrm{a}$ & $18,83 \mathrm{a}$ & $19,52 \mathrm{a}$ & $19,52 \mathrm{a}$ \\
\hline b3 $\left(15\right.$ ton $\left.\mathrm{ha}^{-1}\right)$ & $13,89 \mathrm{a}$ & $14,96 \mathrm{a}$ & $16,13 \mathrm{a}$ & $17,78 \mathrm{a}$ & $18,59 \mathrm{a}$ & $18,60 \mathrm{a}$ \\
\hline Nilai BNJ 0,05 & 1,32 & 1,83 & 2,55 & 2,06 & 2,52 & 2,57 \\
\hline Varietas & & & & & & \\
\hline Numbu & $12,58 \mathrm{~b}$ & $13,95 b$ & $15,48 \mathrm{a}$ & $16,69 b$ & $17,43 \mathrm{a}$ & $17,56 \mathrm{a}$ \\
\hline Keller & $13,90 \mathrm{a}$ & $14,67 \mathrm{ab}$ & $16,94 \mathrm{a}$ & $18,71 \mathrm{a}$ & $18,73 \mathrm{a}$ & $18,84 \mathrm{a}$ \\
\hline Wray & $13,92 \mathrm{a}$ & $15,76 \mathrm{a}$ & $17,13 \mathrm{a}$ & $17,82 \mathrm{ab}$ & $19,21 \mathrm{a}$ & $19,32 \mathrm{a}$ \\
\hline Nilai BNJ 0,05 & 1,03 & 1,43 & 2,00 & 1,61 & 1,97 & 2,01 \\
\hline
\end{tabular}

Keterangan: Angka yang diikuti huruf yang sama pada umur yang sama dalam setiap kolom tidak berbeda nyata berdasarkan uji BNJ $5 \%$. 
Tabel 7. Pengaruh interaksi antara bahan organik dan varietas sorgum terhadap jumlah daun tanaman sorgum ratoon 1 pada umur 4 mst

\begin{tabular}{|c|c|c|c|c|}
\hline \multirow{2}{*}{ Varietas } & \multicolumn{4}{|c|}{ Dosis Bahan Organik (ton $\mathrm{ha}^{-1}$ ) } \\
\hline & 0 & 5 & 10 & 15 \\
\hline & \multicolumn{4}{|c|}{ 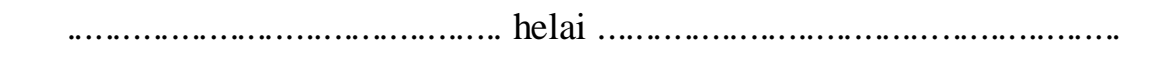 } \\
\hline \multirow{2}{*}{ Numbu } & $5,50(b)$ & $6,86(a)$ & $6,67(a)$ & 7,13 (a) \\
\hline & $\mathrm{B}$ & A & A & A \\
\hline \multirow{2}{*}{ Keller } & $5,87(b)$ & $6,93(a b)$ & 7,27 (a) & $7,20(a)$ \\
\hline & B & A & A & A \\
\hline \multirow{2}{*}{ Wray } & 7,07 (a) & 6,93 (a) & 7,40 (a) & 7,80 (a) \\
\hline & A & A & A & A \\
\hline
\end{tabular}

Keterangan: Angka yang diikuti huruf yang sama (huruf kecil = horizontal, huruf besar $=$ vertikal) tidak berbeda nyata berdasarkan uji BNJ $5 \%$.

Tabel 8. Pengaruh interaksi bahan organik dan varietas sorgum terhadap bobot brangkasan basah tanaman sorgum ratoon 1.

\begin{tabular}{|c|c|c|c|c|}
\hline \multirow{2}{*}{ Varietas } & \multicolumn{4}{|c|}{ Dosis Bahan Organik (ton ha ${ }^{-1}$ ) } \\
\hline & 0 & 5 & 10 & 15 \\
\hline & \multicolumn{4}{|c|}{ kg/tanaman } \\
\hline \multirow{2}{*}{ Numbu } & $0,25(\mathrm{a})$ & $0,23(\mathrm{a})$ & $0,35(\mathrm{a})$ & $0,34(\mathrm{a})$ \\
\hline & A & $\mathrm{B}$ & A & A \\
\hline \multirow{2}{*}{ Keller } & $0,30(a)$ & $0,38(a)$ & $0,50(a)$ & $0,45(a)$ \\
\hline & A & $\mathrm{AB}$ & A & A \\
\hline \multirow{2}{*}{ Wray } & 0,39 (a) & $0,54(\mathrm{a})$ & $0,35(\mathrm{ab})$ & $0,26(b)$ \\
\hline & A & A & A & A \\
\hline Nilai BNJ 0,05 & 0,20 & & & \\
\hline
\end{tabular}

Keterangan: Angka yang diikuti huruf yang sama (huruf kecil = horizontal, huruf $\quad$ besar = vertikal) tidak berbeda nyata berdasarkan uji BNJ $5 \%$.

tentu menghasilkan bobot biji/ malai yang tinggi pula. Pada varietas Keller memiliki nilai rata-rata bobot brangkasan kering tertinggi, tetapi memberikan hasil yang rendah dibandingkan dengan varietas Numbu, sebaliknya pada varietas Numbu memiliki nilai rata-rata bobot brangkasan kering yang rendah, tetapi memberikan hasil yang tinggi dibandingkan dengan varietas Keller dan Wray. Hal ini karena adanya perbedaan genetik oleh varietas sorgum yang digunakan. Menurut Ginting (1991), bahwa tanaman yang berbeda varietas mempunyai pertumbuhan yang berbeda-beda walaupun ditanam pada tanah yang sama.

Pada penilitian ini menunjukkan bahwa perbedaan dosis bahan organik memberikan pengaruh yang nyata terhadap pertumbuhan dan hasil tanaman sorgum ratoon
I, kecuali pada diameter batang, bobot brangkasan basah, bobot brangkasan kering, panjang malai dan jumlah biji/ malai. Pada Tabel 5 aplikasi dosis bahan organik 15 ton ha $^{-1}$ menunjukkan hasil bobot biji/ malai sorgum ratoon I yang lebih tinggi daripada dosis bahan organik 0,5 , dan 10 ton ha ${ }^{-1}$; yaitu 45,64 g/tanaman atau setara 285,25 $\mathrm{g} / \mathrm{m}^{2}$ sedangkan, dosis bahan organik $0,5,10$ ton ha ${ }^{-1}$ menghasilkan bobot biji/ malai masing-masing yaitu 28,04 $\mathrm{g} /$ tanaman atau setara $175,25 \mathrm{~g} / \mathrm{m}^{2} ; 31,29 \mathrm{~g} /$ tanaman atau setara $195,56 \mathrm{~g} / \mathrm{m}^{2}$; dan $39,40 \mathrm{~g} /$ tanaman atau setara $246,25 \mathrm{~g} / \mathrm{m}^{2}$.

Perlakuan varietas sorgum menunjukkan perbedaan pertumbuhan dan hasil tanaman sorgum ratoon I yang nyata, kecuali pada tinggi tanaman. Pada Tabel 5 hasil bobot brangkasan kering yang menunjukkan 
hasil terbaik adalah varietas Keller dengan 0,09 kg/ tanaman atau setara $0,56 \mathrm{~kg} / \mathrm{m}^{2}$ sedangkan, varietas Wray dan Numbu menghasilkan bobot brangkasan kering masing-masing, yaitu $0,08 \mathrm{~kg} /$ tanaman atau setara 0,5 $\mathrm{g} / \mathrm{m}^{2}$ dan $0,07 \mathrm{~kg} /$ tanaman atau setara $0,43 \mathrm{~g} / \mathrm{m}^{2}$. Pada komponen hasil yang menunjukkan hasil bobot biji/malai tertinggi adalah varietas Numbu dengan 55,37 g/tanaman atau setara $346,06 \mathrm{~g} / \mathrm{m}^{2}$ sedangkan, varietas Keller dan Wray menghasilkan bobot biji/ malai masing-masing, yaitu 29,61 g/tanaman atau setara 185,06 g/m $\mathrm{m}^{2}$ dan 23,30 $\mathrm{g} /$ tanaman atau setara dengan $145,62 \mathrm{~g} / \mathrm{m}^{2}$ (Tabel 7). Hal ini selaras dengan penelitian Pramanda (2014), bahwa komponen hasil jumlah biji/malai, bobot biji/malai, dan bobot 100 butir biji varietas Numbu memberikan hasil terbaik.

Hasil penelitian ini, tentunya dapat menguntungkan dan bermanfaat bagi pembudidaya tanaman sorgum. Penggunaan dosis bahan organik 15 ton ha ${ }^{-1}$ dengan varietas Numbu sangat tepat dalam budidaya tanaman sorgum ratoon I untuk menghasilkan bobot biji/ malai yang tinggi namun, bila menginginkan hasil bobot brangkasan basah yang tinggi pada tanaman sorgum ratoon I maka penggunaan dosis bahan organik 5 ton/ ha dengan varietas Wray sangat tepat, brangkasan ini dapat digunakan sebagai bahan pakan ternak.

\section{KESIMPULAN}

Berdasarkan hasil dan pembahasan yang telah diuraikan maka dapat diambil kesimpulan bahwa: Perlakuan dosis bahan organik 15 ton/ha menghasilkan bobot biji/ malai sorgum ratoon I lebih tinggi yaitu 45,64 $\mathrm{g} /$ tanaman atau setara $285,25 \mathrm{~g} / \mathrm{m}^{2}$; Varietas Numbu menunjukkan hasil bobot biji/ malai sorgum ratoon I tertinggi yaitu 55,37 g/tanaman atau setara $346,06 \mathrm{~g} / \mathrm{m}^{2}$ sedangkan, varietas Wray menghasilkan bobot brangkasan basah tertinggi, yaitu $0,54 \mathrm{~kg} /$ tanaman atau setara $3,37 \mathrm{~kg} / \mathrm{m}^{2}$; dan kombinasi antara dosis bahan organik dan varietas sorgum yang tepat untuk menghasilkan bobot brangkasan basah tertinggi adalah dosis bahan organik 5 ton/ha dengan varietas Wray yaitu $0,54 \mathrm{~kg} /$ tanaman atau setara $3,37 \mathrm{~g} / \mathrm{m}^{2}$

\section{DAFTAR PUSTAKA}

Gardner, F. P., R. B. Pearce, dan R. L. Mitchell. 1991. Fisiologi Tanaman Budidaya Terjemahan Herawati Susilo. Universitas Indonesia Press. Jakarta. 428 hal.

Ginting, M. 1991. Pengujian Pupuk Komplesal dan Hasil Tanaman Kedelai (Glicine max (L.) Merril. Skripsi. Fakultas Pertanian Universitas Syiah Kuala. Darussalam-Banda Aceh. 32 hlm.

Hamim, H. Dan Sunyoto. 2011. Penampilan Agronomi Beberapa Genotipe Sorgum (Sorghun bicolor (L.) Moench) Pada Tingkat Pemupukan Nitrogen Berbeda. Prosiding Seminar Hasil-Hasil Pertanian dan Pengabdian Kepada Masyarakat. Lembaga Penelitian Universitas Lampung. Bandar Lampung.

Mudjisihono, R., dan D. S.Damarjati. 1987. Prospek kegunaan Sorghum sebagai sumber pangan dan pakan ternak. J. Litbang Pertanian 6(1): 1-4.

Pramanda, R. P. 2014. Pengaruh Aplikasi Bahan Organik Terhadap Pertumbuhan Dan Hasil Beberapa Varietas Sorgum (Sorghum bicolor L. Moench). Skripsi. Fakultas Pertanian Universitas Lampung. Bandar Lampung.

Septiani, R. 2009. Evaluasi Pertumbuhan dan Hasil Beberapa Genotipe Sorgum (Sorghun bicolor (L.) Moench) Ratoon I. Skripsi. Fakultas Pertanian Universitas Lampung. Bandar Lampung.

Sitompul, S. M. Dan B. Guritno. 1995. Analisis pertunbuhan Tanaman. Gadjah Mada University Press. Yogyakarta.

Sucipto, 2010. Efektifitas Cara Pemupukan Terhadap Pertumbuhan dan Hasil Beberapa Varietas Shorgum Manis (Sorghum bicolor L. Moench). Jurnal Embryo. 7 (2): 67-74.

Tarigan, Dewi H., T. Irmansyah, E. Purba. 2013. Pengaruh Waktu Penyiangan Terhadap Pertumbuhan dan Produksi Beberapa Varietas Sorgum (Sorghum bicolor (L.) Moench). Jurnal Online Agroteknologi, Vol. 2, No. 1:86-94.

Wahida, N. R. Sennang dan H. L. Hernusye. 2011. Aplikasi Pupuk Kandang Ayam Pada Tiga Varietas Sorgum (Sorghum bicolor L. Moench). Skripsi. Fakultas Pertanian Universitas Hasanuddin. Makassar. 